\title{
Benthic metabolism in a natural coastal petroleum seep $^{*}$
}

\author{
Paul A. Montagna ${ }^{1, * *}{ }^{\text {James E. Bauer }}{ }^{2}$, Maria C. Prieto ${ }^{1}$, Dane Hardin ${ }^{2}$ \\ \& Robert B. Spies ${ }^{1}$ \\ ${ }^{1}$ University of California, Lawrence Livermore National Laboratory, Environmental Sciences Division, PO Box 5507. \\ L-453 Livermore, California 94550, USA \\ ${ }^{2}$ Kinnetic Laboratories, Inc., PO Box 1040, 3050 Paul Sweet Road, Santa Cruz, California 95061, USA
}

\begin{abstract}
The rates of 3 processes known to be mediated by microbial metabolic activity were measured in the sediments of a shallow-water ( $18 \mathrm{~m}$ depth) natural petroleum seep and a nearby nonseep area near Santa Barbara, California. Measurements of oxygen flux, hydrocarbon degradation, and sulfate reduction were made in the sediments of 3 stations with varying amounts of petroleum seepage. At the seep, 1 station was at the margin of active seepage while the 2 nd station ( $20 \mathrm{~m}$ away) had moderate seepage. A 3rd non-seep station was $2.4 \mathrm{~km}$ away from the petroleum seep area. Total oxygen flux was not statistically different among the 3 stations studied. Rates of sulfate reduction and hydrocarbon degradation were greater at seep than non-seep sites. Within the seep area, greater rates of sulfate reduction and hydrocarbon degradation were found at the station of moderate seepage than at the margin of active oil and gas seepage. The greater rates of metabolism at the seep correlate with previous findings of higher amounts of ATP and macroinfauna at the seep. We hypothesize that the higher abundances of infauna and concentrations of ATP at the seep are sustained by heterotrophic bacterial degradation of petroleum and the consumption of those bacteria by infauna.
\end{abstract}

\section{INTRODUCTION}

Natural submarine petroleum seeps are abundant off the southern California coast. One particularly active seep, the Isla Vista seep, is located off Coal Oil Point, Santa Barbara, California, and its effect upon the local biota, particularly the benthos, has been the subject of several recent studies (Spies et al. 1980, Spies \& DesMarais 1983, Montagna \& Spies 1985).

Contrary to what might be expected in an environment that is permeated with potentially toxic hydrocarbons, there is an abundant benthic community associated with the Isla Vista seep. Macroinfaunal densities are higher at the seep than at a comparable non-seep site and diversity is similar at both sites (Spies \& Davis 1979, Davis \& Spies 1980). The seep benthos is also characterized by mats of the sulfide-oxidizing bacteria Beggiatoa spp. and sediments that contain greater

- University of Texas at Austin, Marine Science Institute, Contribution No. 674

- Present address: The University of Texas at Austin, Marine Science Institute, Port Aransas, Texas 78373, USA quantities of ATP, particularly near active petroleum seepage (Spies et al. 1980). The mats of Beggiatoa spp. are also rich in chlorophyll (Montagna \& Spies 1985), and Beggiatoa spp. appear to be a food source for invertebrates (Spies \& DesMarais 1983, Howarth 1984, Stein 1984). Stable carbon isotope ratios and the natural abundance of ${ }^{14} \mathrm{C}$ in invertebrate tissues suggest that petroleum carbon is incorporated into the coastal food web via decomposition of petroleum by heterotrophic bacteria. The greater abundance of infauna and apparent incorporation of petroleum into the benthic community in oil seeps has been interpreted as 'trophic or organic enrichment' (Spies \& Davis 1979, Spies et al. 1980, Spies \& DesMarais 1983).

Although static measurements (e.g. infaunal densities and ATP concentrations) are greater in areas of petroleum seepage, overall production may not be greater if organism turnover time or metabolic rates are not at least equal to those in other areas. However, if productivity is greater at the seep then rates of benthic metabolism should also be greater.

There are a number of ways to measure benthic metabolism. Although several approaches for meas- 
uring oxidation of organic material are available, e.g. election transport chain activity (Pamatmat \& Bhagwat 1973) and measurement of heat production (Pamatmat 1982), oxygen uptake at the sediment surface is a good indicator of total metabolism within the sediment (Patching \& Raine 1983, Howes et al. 1984). Hydrocarbon degradation is one aerobic process that may be important in an oil seep community and is probably limited to oxygen-containing surface sediments (Atlas 1981, Bauer \& Capone 1985). Sulfur cycling is also known to be an important route by which carbon and energy flow via anderobic respiration in salt marsh and subtidal sediments (Howarth \& Teal 1980, Howarth 1984). In sediments such as those at the Isla Vista seep, sulfur cycling may be altered due to the presence of carbon in the forms of petroleum and its metabolites and to the availability of oxygen. In this study we measured rates of oxygen flux, hydrocarbon degradation, and sulfate reduction in order to assess the relative roles of aerobic and anaerobic metabolism at 3 sites of varying distance from actively seeping petroleum in and near the Isla Vista petroleum seep.

\section{MATERLALS AND METHODS}

Study site and stations. The study area is located between Coal Oil Point and Goleta Point, Santa Barbara, California, USA. Three stations at increasing distances from active seepage and experiencing different amounts of petroleum exposure were chosen for study. Station A is within the Isla Vista seep and at the margin of an area where large quantities of fresh petroleum and natural gas are seeping from the sediments into the overlying water column. Station $B$, about $20 \mathrm{~m}$ north of $\mathrm{A}$, has much less fresh oil seepage, but has large quantities of weathered, asphalt-like tar 4 to $12 \mathrm{~cm}$ below the sediment surface. Station $C$ has no active petroleum seepage, is $1.4 \mathrm{~km}$ east of the Isla Vista seep, and has about 4.8 times less total hydrocarbons than Stn B (Stuermer et al. 1982). Stns B and C were previously studied in great detail and have similar granulometry (Spies \& Davis 1979). Stns A and B are within the Isla Vista seep, but $\operatorname{Stn} C$ is not. All stations were at a depth of $18 \mathrm{~m}$ in fine-sand sediments.

Oxygen flux. Cylindrical in situ benthic chambers were constructed of clear acrylic. A 'crossed-paddle' stirrer with a handle protruding through the top of the chamber was employed so divers could manually stir the water before sampling. Each chamber measured $59.5 \mathrm{~cm}$ internal diameter (i.d.), $20.2 \mathrm{~cm}$ in height, covered a bottom area of $0.28 \mathrm{~m}^{2}$ and contained $51 \mathrm{l}$ of water after being inserted $2 \mathrm{~cm}$ into the sea floor. Opaque benthic chambers were identical to clear chambers in dimensions, but were covered with both duct tape and dark plastic material.
Clear and opaque water bottles were constructed to serve as controls for effects due to water containment alone. Clear bottles consisted of acrylic cylinders $11.6 \mathrm{~cm}$ i.d. and $61.5 \mathrm{~cm}$ long; opaque bottles consisted of PVC cylinders $9.5 \mathrm{~cm}$ i.d. and $75.5 \mathrm{~cm}$ long. Clear and opaque bottles held volumes of 6.5 and 5.4 l, respectively. The design of the bottles was similar to that of Van Dorn sampling bottles with rubber endcaps.

Each chamber and bottle had 2 water entrance ports at opposite ends with Mohr clamps attached: one was used for water sampling, the other for water replacement. Both ports on the chambers were opened during installation. Chambers were pushed into the sediments approximately $2 \mathrm{~cm}$ by divers with as little disturbance of the sediment as possible. Prior to sampling, chambers were manually stirred to disrupt any oxygen gradient that may have been present. Constant stirring was not employed so that changes in oxygen concentrations are probably minimum values, since stirring increases oxygen flux (Boynton et al. 1981). Water samples were taken with $60 \mathrm{~cm}^{3}$ plastic syringes that had been flushed once to eliminate residual air bubbles and the initial volume of water trapped in the sampling tube. Ports were opened to take the samples and were closed again immediately. Water samples were withdrawn slowly to avoid degassing.

To compare oxygen flux at 3 stations would require that all 4 incubation devices be sampled synoptically at all 3 sites. Thus, the minimum number of samples without replication is 12 . It was not possible to sample all 3 stations with replication because of limitations on diver's bottom time and the number of samples that could be processed in the laboratory. It was, however, possible to obtain a facsimile of replication by employing a randomized complete block design and repeating the entire experiment on 3 consecutive days. Days were blocks and stations were treatments, and it was assumed that there was no days-station interaction. To assess the loss of sample precision by not employing a completely random design, i.e. synoptic replicates, we performed an experiment in which all 12 incubation devices were deployed at Stn B. This allowed us to calculate the percent variability due to replication for a given site-day combination. Thus, a measure of withinsite variability was obtained separately.

The first experiment in July 1985 was conducted to determine variability between chambers and bottles within one site. All chambers ( 3 light, 3 dark) and bottles ( 3 light, 3 dark) were placed at Stn B. Stn B was selected because we had anticipated it sharing characteristics with both Stns A and C, which appear to be distinctly different from each other. In this first experiment, samples were taken at 0,3 and $6 \mathrm{~h}$. Oxygen concentrations in the chambers were analyzed statisti- 
cally by using a variance components analysis procedure (SAS 1985). There were 4 sources of variability: incubation time, incubation chamber type, replicate chambers (a nested factor, because samples were drawn from a given chamber over time), and experimental technique which includes random error and precision. This design is a completely random, partially hierarchical design, and details of the statistical model used are given in Kirk (1982; p. 474).

The second experiment was conducted to determine if differences among stations existed. In August 1985 a light and dark chamber and a light and dark bottle were deployed at each of the 3 stations. Bottom-water oxygen concentrations, temperature, and light levels at each station (outside the chambers) were monitored concurrently. Light intensities were measured with a Li-cor (Lincoln, Nebraska, USA) Li-185b meter and 'UW Quantum' sensor held by divers $1 \mathrm{~m}$ above the sediment surface. Incubations were carried out for two $2 \mathrm{~h}$ periods. The initial $2 \mathrm{~h}$ period was used to determine net photosynthesis (NP), the change in oxygen concentrations in the light chamber minus the change in the light bottles, and total oxygen demand (TOD), the change in concentrations in the dark chamber minus the change in the dark bottles. Gross photosynthesis (GP) is the difference between NP and TOD (which is a negative value). Concentration changes were converted to flux values by taking into account the area covered by the chambers and the volume of water contained in the chamber. After $2 \mathrm{~h}$, chambers and bottles were poisoned with formaldehyde to a final concentration of $0.1 \%$ formalin, which killed all visible macrofauna. Chambers were sampled again $2 \mathrm{~h}$ after poisoning to determine chemical oxygen demand (COD), the change in oxygen concentration in the chambers corrected for changes in the bottles. The poisoning technique does not provide exact values of chemical oxidation, since anaerobic metabolism will continue because of the time it takes for formaldehyde to diffuse into sediments, an effect which is probably enhanced by the lack of bioturbation (Dale 1978). Because the depth of the aerobic-anaerobic interface is greatest at $\operatorname{Stn} C$ and shallowest at Stn $A$, it is likely that the COD calculated for the formaldehyde-treated sample at Stn A is more accurate than that calculated for Stn C. Biological oxygen demand, i.e. respiration (R), was determined by subtracting COD from TOD.

The sampling scheme to measure oxygen flux was followed for 3 consecutive days. Each day at the end of the experiment, chambers were inverted and bottles were left opened. The following day bottles were flushed several times with bottom water and chambers were set back in a slightly different place to avoid possible artifacts due to the previous formaldehyde treatment.
During the July experiment, dissolved oxygen content of the water was measured using a spectrophotometric method for low oxygen concentrations (Broenkow \& Cline 1969). We had expected the bottom water at the seep to be low in oxygen because sulfide is abundant in the interstitial water of surface sediments (Spies et al. 1980). Sulfide was measured at each sampling time in July using a colorimetric technique (Cline 1969), but no sulfide was found in any of the chambers at Stn B. Oxygen concentrations were, however, close to saturation. Therefore, during August dissolved oxygen was measured following the Winkler modification of Strickland \& Parsons (1972), which applies for a wider range of concentrations.

Sulfate reduction. Rates of sulfate reduction were measured in vertical sediment profiles at the 3 stations in August and September 1985. The method developed by Jorgensen (1978) was employed with slight modification. Plastic syringe corers $\left(10 \mathrm{~cm}^{3}\right)$ were used by divers to collect sediment to a depth of approximately $6 \mathrm{~cm}$. Cores were stoppered and transported on ice back to the Lawrence Livermore National Laboratory (LLNL). Injections of ${ }^{35} \mathrm{SO}_{4}^{-}(10 \mu l$ containing approximately $1 \mu \mathrm{Ci}$ ) were made by syringe through siliconesealed ports in the sides of the cores. Incubations proceeded for $24 \mathrm{~h}$ at in situ temperature $\left( \pm 2 \mathrm{C}^{\circ}\right)$ and were terminated by freezing the cores.

Within 1 wk of freezing, the cores were sectioned, placed in airtight vials and gassed with $\mathrm{O}_{2}$-free nitrogen to prevent oxidation of any sulfides formed during incubation. Five $\mathrm{ml}$ of $1 \mathrm{~N} \mathrm{H}_{2} \mathrm{SO}_{4}$ were added to each vial with sediment and were periodically shaken for $1 \mathrm{~h}$ to liberate acid-volatile sulfides (AVS). This procedure was found to release greater than $95 \%$ of the AVS within $1 \mathrm{~h}$.

AVS were collected by purging vials with $\mathrm{O}_{2}$-free nitrogen into $5 \mathrm{ml}$ of $2 \%$ zinc-acetate for $1 \mathrm{~h}$ with periodic shaking. The zinc-sulfide precipitate formed was suspended as a gel in $10 \mathrm{ml}$ Insta-Gel (Packard Instruments, Inc., Downers Grove, Illinois, USA). The ${ }^{35} \mathrm{~S}=$ was measured by liquid scintillation counting and quenching was corrected by the external standards method.

Porewater sulfate concentrations were measured concurrently using the barium sulfate precipitation method (APHA 1971). All steps (except for centrifugation) of porewater extraction from sediments were carried out under an oxygen-free nitrogen atmosphere.

Hydrocarbon degradation. The aerobic degradation of several petroleum hydrocarbons was followed in both the sediments and overlying water at Stns A, B, and $C$. Diver-collected sediment cores $\left(10 \mathrm{~cm}^{3}\right.$ syringe barrels with bottoms cut off) or bottom water were transported on ice to LLNL where they were processed within $24 \mathrm{~h}$. 
Details of the incubations and analytical techniques used are described in Bauer \& Capone (1985) and Herbes \& Schwall (1978). The top $1 \mathrm{~cm}$ of the cores $\left(1.5 \mathrm{~cm}^{3}\right.$ of sediment) was placed in acid-washed vials with $1 \mathrm{ml}$ of $0.2 \mu \mathrm{m}$ filtered seawater. For bottom-water incubations, $5 \mathrm{ml}$ of unfiltered water were added to vials. Autoclaved controls were incubated in parallel with all live samples. Ten $\mu$ l of an acetone solution $(\sim 0.05 \mu \mathrm{Ci})$ of $\mathrm{n}-\left[1-{ }^{14} \mathrm{C}\right]$ hexadecane, $\left[1(4,5,8)-{ }^{14} \mathrm{C}\right]$ naphthalene or $\left[9(10)-{ }^{14} \mathrm{C}\right]$ anthracene (Amersham, Arlington Heights, Illinois, USA) were added to the samples. Samples were incubated for 5 to $7 \mathrm{~d}$ in a seawater table at $12.5^{\circ} \mathrm{C}$.

Periodic measurements were made of the ${ }^{14} \mathrm{C}$-label evolved as ${ }^{14} \mathrm{CO}_{2}$ through mineralization, as ${ }^{14} \mathrm{C}$-label incorporated to cellular biomass or that present as metabolic intermediates (Herbes \& Schwall 1978, Bauer \& Capone 1985). The ${ }^{14} \mathrm{CO}_{2}$ mineralized from ${ }^{14} \mathrm{C}$-labeled hydrocarbons was measured by flushing the sample headspace with compressed air and trapping it in $10 \mathrm{ml}$ 'Oxosol- ${ }^{14} \mathrm{C}$ ' (National Diagnostics, Somerville, New Jersey, USA). To measure ${ }^{14} \mathrm{C}$-label present as metabolic intermediates or incorporated into cellular biomass samples were purged of ${ }^{14} \mathrm{CO}_{2}$, $15 \mathrm{ml}$ acetone was added, and samples were subjected to Sohxlet extraction for $8 \mathrm{~h}$. One $\mathrm{ml}$ of the acetone extract was added to $5 \mathrm{ml}$ Insta-Gel (Packard Instruments, Inc., Downers Grove, Illinois, USA). A fraction $(100$ to $200 \mathrm{mg})$ of the dried, extracted sediment pellet was added to $5 \mathrm{ml}$ distilled water and $15 \mathrm{ml}$ Insta-Gel to form a suspension. ${ }^{14} \mathrm{C}$ in samples was quantified on a Packard Tri-Carb liquid scintillation counter (Packard Instruments, Inc.) and corrected for quench by either the internal or external standards methods.

\section{RESULTS}

\section{Experimental precision in oxygen studies}

The first set of experiments was conducted in July 1985 to assess the precision of measuring changes in oxygen concentration. This was important because replication was not planned for in later studies to determine if there were differences among stations.

Two sources of variation, interaction and replicate chamber variability, were negligible, each accounting for less than $2 \%$ of the total variance (Table 1 ). This indicated that a block design, i.e. replicating by repeating the entire experiment, would be adequate for testing for differences among stations because we could expect parallel responses for chamber types over time, and replicate chambers were not a large source of variability. As would be expected, the experimental treatments, incubation time, and chamber type accounted for a total of $65.5 \%$ of the variability in oxygen concentration changes. However, a large amount of the variability $(31 \%)$ was due to the colorimetric technique and random error (Table 1). Therefore, during the second experiment in August, when differences among stations would be tested, Winkler titrations were used to increase the precision of the method.

Even though the amount of variability due to technique is very high, the coefficient of variation (CV) for oxygen flux measurements was not unacceptably high. The CV was $73 \%$ for TOD and only $41 \%$ for NP. Since the flux is estimated from the mean of chambers minus the mean of bottles, the variance of the flux is the sum of the variance of the chambers and the variance of the bottles (Kempthorne \& Allmaras 1965).

\section{Oxygen flux}

Water column conditions at the study sites were different on each of the 3 days of the oxygen flux study in August 1985. Light intensities rose $50 \%$ from the first day to the second and doubled from the second to the third day ( $\mathrm{p}=0.016$; Table 2$)$. There was a concomitant rise in oxygen concentration from Day 1 to Day 2, but there was no significant rise in oxygen concentration on Day 3. Stn A generally had lower light intensities while Stn $C$ had the highest light intensities, but there were no statistically significant differences between sites for either light $(p=0.30)$, temperature $(\mathrm{p}=0.33)$, or oxygen concentration $(\mathrm{p}=0.99)$ for among days. The dominant factors seemed to be changes in light intensity and temperature during the course of a day ( $p=0.006$ and 0.003 , respectively) (Table 2).

Rates for oxygen flux were calculated from the changes in oxygen concentration, as described above, and are shown in Table 3. No significant differences in any of the processes affecting total oxygen flux were found among sampling dates or stations (2-way ANOVA without the interaction term). The processes measured (GP, NP, R, and COD) were analyzed in

Table 1. Variance component analysis of oxygen concentrations at Stn B for Jul 1985. The variance due to each component in the experimental design is given as a percent of the total variance. Parentheses indicate a nested factor

\begin{tabular}{|lc|}
\hline Variance component & Percent \\
\hline Incubation time & 33.2 \\
Chamber type & 32.3 \\
Time $\times$ Type interaction & 2.0 \\
Replicate chamber (Time $\times$ Type) & 1.6 \\
Technique & 30.9 \\
\hline
\end{tabular}


multivariate mode and no significant differences between sampling dates and stations were found. The mean net fluxes for all dates and stations at midday (in $\mathrm{mmol} \mathrm{m} \mathrm{m}^{-2} \mathrm{~h}^{-1}$ ) were 2.07 for $\mathrm{R}, 0.53$ for COD, and 3.06 for GP. The statistical tests for station differences, which were calculated using dates as blocks, rely on the assumption that there is no interaction between dates and stations. This assumption is unreasonable for part of the data (Fig. 1). All 3 stations exhibited approximately similar rates of total oxygen flux on August 14 and August 15. However, on August 13 Stns B and C exhibited much lower oxygen fluxes than Stn A (Fig.
1). Since there is an interaction between days and stations, the statistical tests planned are inappropriate, and it appears that the average total oxygen fluxes (in mmol $\mathrm{m}^{-2} \mathrm{~d}^{-1}$ ) of -12 at Stn $\mathrm{C}_{1}-25$ at $\operatorname{Stn} \mathrm{A}_{\text {, and }}-41$ at Stn B are probably not different.

\section{Sulfate reduction}

On both sampling dates, rates of sulfate reduction were different among stations but there was no trend with sediment depth (2-way ANOVA, $p \leq 0.0005)$. Sul-

Table 2. Diel water column conditions during the oxygen flux study (Aug 1985). Since there were no differences among the stations for light, temperature and oxygen, mean values for all stations are presented

\begin{tabular}{|c|c|c|c|c|}
\hline Date & Time & $\begin{array}{c}\text { Light } \\
\left(\mu \mathrm{E} \mathrm{m}^{-2} \mathrm{~s}^{-1}\right)\end{array}$ & $\begin{array}{c}\text { Temperature } \\
\left({ }^{\circ} \mathrm{C}\right)\end{array}$ & $\begin{array}{c}\text { Oxygen } \\
\left(\mu \mathrm{g} \text {-at } \mathrm{I}^{-1}\right)\end{array}$ \\
\hline $13 \mathrm{Aug}$ & $\begin{array}{l}\text { AM } \\
\text { Noon } \\
\text { PM } \\
\text { Mean }\end{array}$ & $\begin{array}{r}71 \\
123 \\
\frac{112}{102}\end{array}$ & $\begin{array}{l}14.7 \\
- \\
\overline{14.7}\end{array}$ & $\begin{array}{l}412 \\
415 \\
\frac{477}{435}\end{array}$ \\
\hline 14 Aug & $\begin{array}{l}\text { AM } \\
\text { Noon } \\
\text { PM } \\
\text { Mean }\end{array}$ & $\begin{array}{l}178 \\
190 \\
\frac{113}{160}\end{array}$ & $\begin{array}{l}15.2 \\
14.9 \\
14.8 \\
15.0\end{array}$ & $\begin{array}{l}502 \\
521 \\
\frac{510}{511}\end{array}$ \\
\hline $15 \mathrm{Aug}$ & $\begin{array}{l}\text { AM } \\
\text { Noon } \\
\text { PM } \\
\text { Mean }\end{array}$ & $\begin{array}{l}165 \\
733 \\
\frac{200}{366}\end{array}$ & $\begin{array}{l}16.8 \\
17.3 \\
15.2 \\
16.4\end{array}$ & $\begin{array}{l}528 \\
518 \\
515 \\
520\end{array}$ \\
\hline
\end{tabular}

Table 3. Oxygen flux in Aug $1985\left(\mathrm{mmol} \mathrm{O}_{2} \mathrm{~m}^{-2} \mathrm{~h}^{-1}\right.$ or $\left.\mathrm{d}^{-1}\right)$. Total flux $=(\mathrm{GP} \times$ daylight, $\mathrm{h})-([\mathrm{COD}+\mathrm{R}] \times 24 \mathrm{~h})$. Total demand $=(\mathrm{COD}+\mathrm{R}) \times 24 \mathrm{~h}$. Total flux and demand were calculated before rounding off GP, COD, and $\mathrm{R}$

\begin{tabular}{|c|c|c|c|c|}
\hline \multirow[t]{2}{*}{ Date } & \multirow[t]{2}{*}{ Process } & \multicolumn{3}{|c|}{ Station } \\
\hline & & A & $\mathrm{B}$ & $\mathrm{C}$ \\
\hline \multirow[t]{7}{*}{13 Aug } & Gross photosynthesis $\left(\mathrm{h}^{-1}\right)$ & 2.6 & 1.3 & 6.8 \\
\hline & Net photosynthesis $\left(\mathrm{h}^{-1}\right)$ & 1.5 & -2.2 & 0.2 \\
\hline & Respiration + chemical $\left(\mathrm{h}^{-1}\right)$ & -1.1 & -3.5 & -6.6 \\
\hline & Chemical oxygen demand $\left(\mathrm{h}^{-1}\right)$ & -1.7 & 0.9 & 2.8 \\
\hline & Respiration $\left(\mathrm{h}^{-1}\right)$ & 0.6 & -4.4 & -9.4 \\
\hline & Total oxygen flux $\left(\mathrm{d}^{-1}\right)$ & 4.1 & -69.3 & -77.1 \\
\hline & Total oxygen demand $\left(\mathrm{d}^{-1}\right)$ & -26.9 & -84.8 & -158.5 \\
\hline \multirow[t]{7}{*}{$14 \mathrm{Aug}$} & Gross photosynthesis $\left(\mathrm{h}^{-1}\right)$ & 6.0 & 2.0 & 4.4 \\
\hline & Net photosynthesis $\left(\mathrm{h}^{-1}\right)$ & 1.8 & -0.5 & 3.1 \\
\hline & Respiration + chemical $\left(\mathrm{h}^{-1}\right)$ & -4.2 & -2.5 & -1.3 \\
\hline & Chemical oxygen demand $\left(\mathrm{h}^{-1}\right)$ & 1.6 & -1.8 & -3.6 \\
\hline & Respiration $\left(\mathrm{h}^{-1}\right)$ & -5.8 & -0.6 & 2.3 \\
\hline & Total oxygen flux $\left(\mathrm{d}^{-1}\right)$ & -29.1 & -35.4 & 20.9 \\
\hline & Total oxygen demand $\left(\mathrm{d}^{-1}\right)$ & -100.5 & -59.2 & -32.0 \\
\hline \multirow[t]{7}{*}{15 Aug } & Gross photosynthesis $\left(\mathrm{h}^{-1}\right)$ & -0.5 & -2.1 & 7.1 \\
\hline & Net photosynthesis $\left(\mathrm{h}^{-1}\right)$ & -2.3 & -1.8 & 4.5 \\
\hline & Respiration + chemical $\left(\mathrm{h}^{-1}\right)$ & -1.8 & 0.3 & -2.7 \\
\hline & Chemical oxygen demand $\left(\mathrm{h}^{-1}\right)$ & -1.7 & 0.3 & -1.6 \\
\hline & Respiration $\left(\mathrm{h}^{-1}\right)$ & -0.1 & -0.0 & -1.1 \\
\hline & Total oxygen flux $\left(\mathrm{d}^{-1}\right)$ & -48.6 & -18.2 & 21.5 \\
\hline & Total oxygen demand $\left(\mathrm{d}^{-1}\right)$ & -43.0 & 6.6 & -63.9 \\
\hline
\end{tabular}




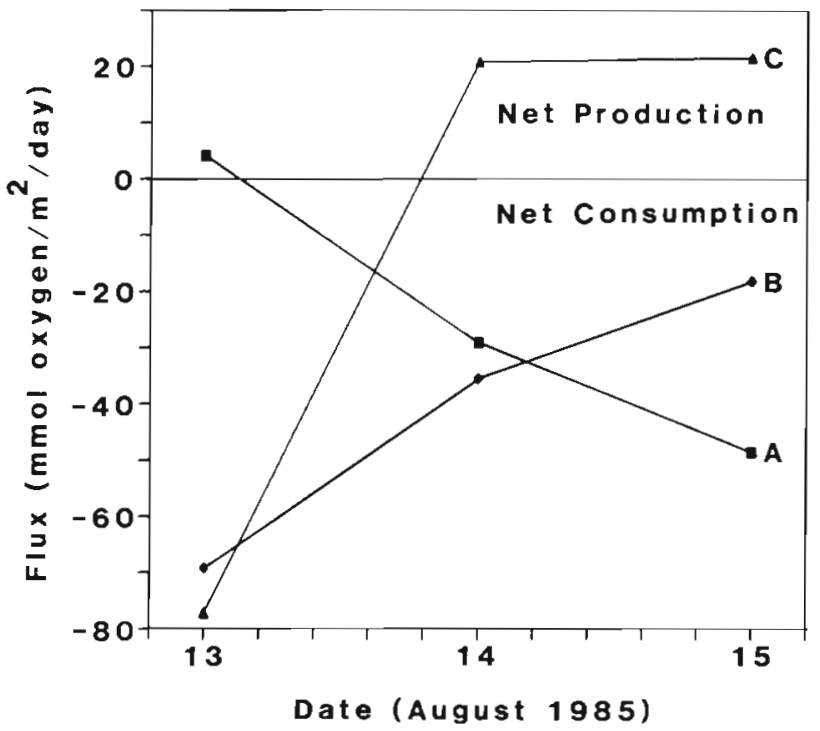

Fig. 1. Total oxygen flux at the 3 stations for Aug 13 to 15 , 1985. Positive values: net oxygen production; negative values: net oxygen consumption

Table 4. Sulfate reduction $\left(\mathrm{nmol} \mathrm{cm} \mathrm{cm}^{-3} \mathrm{~d}^{-1}\right)$ in top $50 \mathrm{~mm}$ of sediments. Rates are for the mean (and standard deviation) from 3 cores

\begin{tabular}{|ccccc|}
\hline Date & $\begin{array}{c}\text { Depth } \\
(\mathrm{mm})\end{array}$ & $\mathrm{A}$ & $\begin{array}{c}\text { Station } \\
\text { B }\end{array}$ & $\mathrm{C}$ \\
\hline 14 Aug & $0-50$ & $19.3(3.6)$ & $27.9(5.5)$ & $3.8(2.1)$ \\
11 Sep & $0-22$ & $2.2(2.5)$ & $29.2(18.0)$ & $3.0(0.6)$ \\
& $23-37$ & $1.2(0.7)$ & $58.4(30.2)$ & $6.9(2.9)$ \\
& $\frac{38-53}{\text { Sum 0-53 }}$ & $\frac{13.6(18.7)}{17.0}$ & $\frac{48.4(45.7)}{136.0}$ & $\frac{12.8(11.3)}{22.7}$ \\
\hline
\end{tabular}

fate reduction rates were highest at $S \operatorname{tn} B$, but rates at Stn A were the same as Stn C (Tukey Test) (Table 4). Rates of sulfate reduction were generally higher during September.

\section{Hydrocarbon degradation}

The mineralization of radiolabeled ${ }^{14} \mathrm{C}$-hexadecane and ${ }^{14} \mathrm{C}$-naphthalene in sediment slurries and bottom water on 5 June 1985 is shown in Fig. 2 \& 3 . In all cases the hydrocarbons were mineralized more rapidly in sediments from Stn B than sediments from Stns A or $\mathrm{C}$ (Fig. 2 to 4, Table 5). Naphthalene (Fig. 2) was mineralized more rapidly than hexadecane (Fig. 4) and, interestingly, was also more rapidly mineralized in bottom water (Fig. 3) than in sediments. Rates of naphthalene mineralization were much greater in August than in June (Table 5).

The partitioning of ${ }^{14} \mathrm{C}$-label derived from ${ }^{14} \mathrm{C}$ -

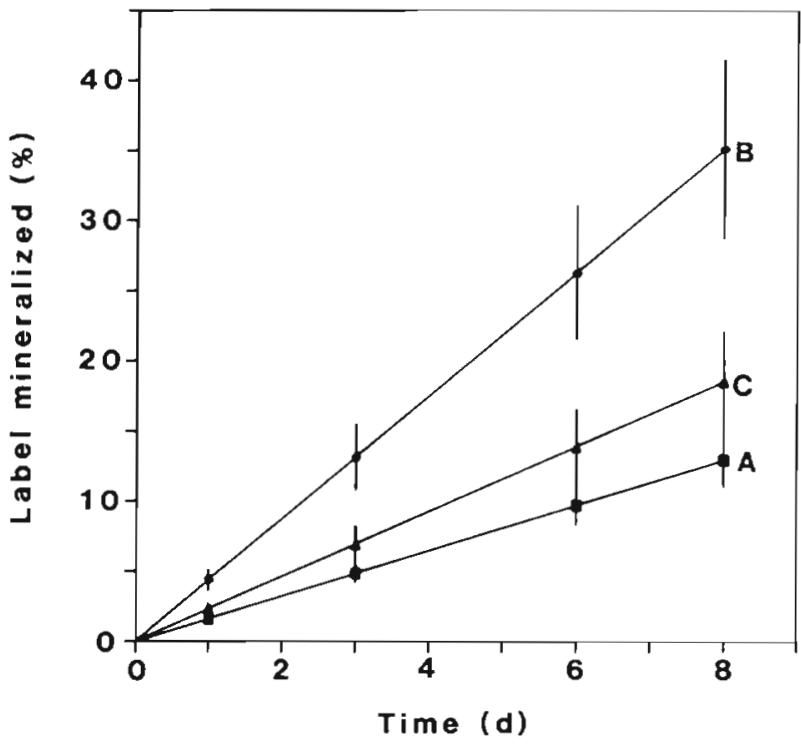

Fig. 2. Mineralization of ${ }^{14} \mathrm{C}$-naphthalene to ${ }^{14} \mathrm{CO}_{2}$ by sediment slurries from Stns $A, B$, and C (0 to $1 \mathrm{~cm}$ depth), Jun 5 1985. Vertical bars: $95 \%$ confidence interval of the estimate

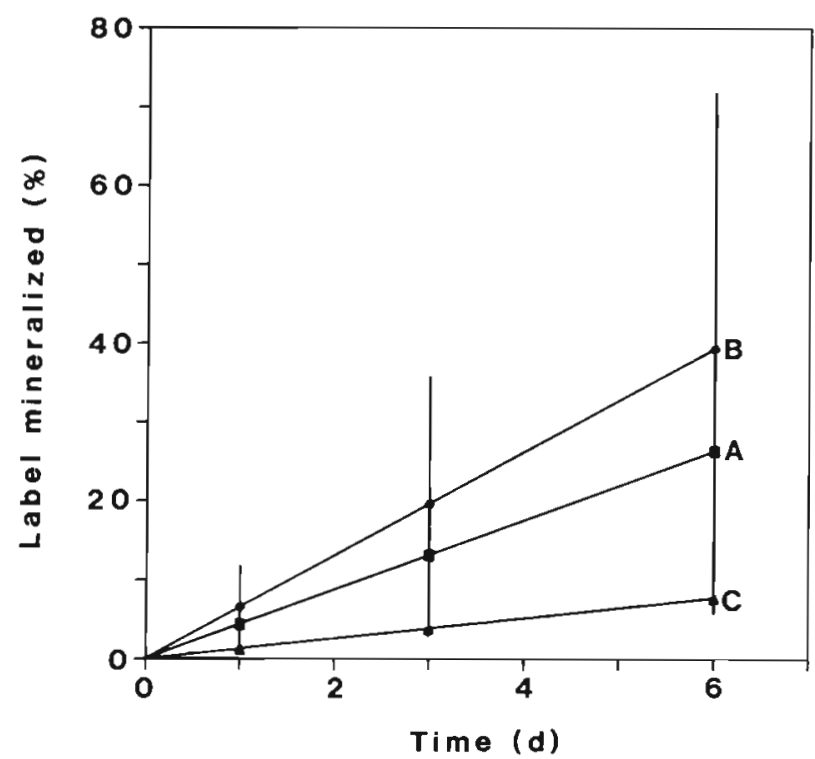

Fig. 3. Mineralization of ${ }^{14} \mathrm{C}$-naphthalene to ${ }^{14} \mathrm{CO}_{2}$ by seawater samples taken above the sediment surface at Stns A, B, and C, Jun 5, 1985. Vertical bars: $95 \%$ confidence interval of the estimate

anthracene into ${ }^{14} \mathrm{CO}_{2}$, intermediate metabolites, parent anthracene, and cellular biomass in sediments from Stns A, B, and C on 26 August 1985 is shown in Fig. 5 to 7. Anthracene, like naphthalene and hexadecane, was mineralized most rapidly in sediments from Stns A and B (Fig. 5 \& 7). Mineralization occurred with no apparent lag in A and B sediments while Stn C showed up to a $2 \mathrm{~d}$ lag period before a significant increase in anthracene mineralization rates occurred 
Table 5. Estimated rates of hydrocarbon mineralization over 5 d in Santa Barbara sediments (\% d ${ }^{-1}$ ) in 1985 (standard error of the estimates in parentheses)

\begin{tabular}{|lcccc|}
\hline Compound & Date & & Station \\
& & A & B \\
\hline Naphthalene & Jun 5 & $1.6(0.1)$ & $4.4(0.4)$ & $2.3(0.2)$ \\
Naphthalene' & Jun 5 & $4.4(1.3)$ & $6.5(2.1)$ & $1.3(0.1)$ \\
Naphthalene & Aug 18 & $11.6(0.8)$ & $15.7(1.7)$ & $8.8(0.0)$ \\
Hexadecane & Jun 5 & $0.12(0.04)$ & $0.79(0.05)$ & $0.057(0.013)$ \\
Anthracene & Aug 18 & $6.5(0.5)$ & $7.8(0.6)$ & $3.7(0.4)$ \\
Anthracene & Aug 18 & 15.8 & 76.3 & 14.5 \\
'Bottom water sample & & & \\
${ }^{2}$ Maximum rate after a lag period & & & \\
\hline
\end{tabular}

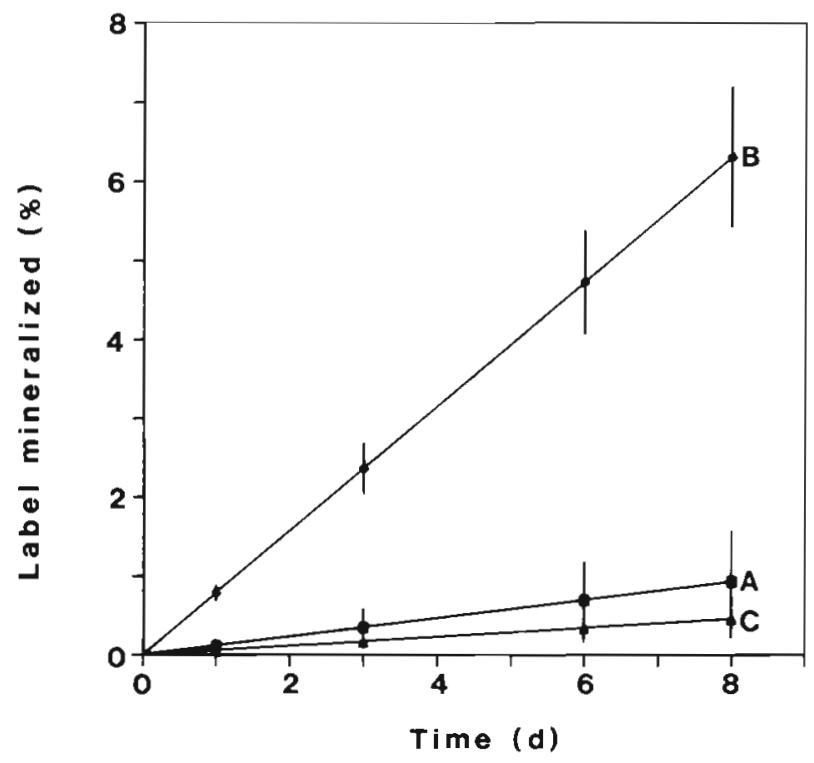

Fig. 4. Mineralization of ${ }^{14} \mathrm{C}$-hexadecane to ${ }^{14} \mathrm{CO}_{2}$ by sediment slurries from Stns $A, B$, and C $(0$ to $1 \mathrm{~cm}$ depth), Jun 5 , 1985. Vertical bars: $95 \%$ confidence interval of the estimate

(Fig. 5). Similar patterns were observed in Sohxlet extracts of sediments (Fig. 6). An immediate and rapid decrease in extractable ${ }^{14} \mathrm{C}$-label occurred in Stn $\mathrm{A}$ and $B$ sediments while Stn C exhibited a 2 d lag before the extractable label decreased (Fig. 6). The fraction of ${ }^{14} \mathrm{C}$-label which was retained by extracted sediments (cellularly incorporated) is shown in Fig. 7. Rapid assimilation of ${ }^{14} \mathrm{C}$ into this component occurred in Stn $\mathrm{A}$ and $\mathrm{B}$ sediments while a $2 \mathrm{~d}$ lag and significantly lower amounts were incorporated in Stn $\mathrm{C}$ sediments.

\section{DISCUSSION}

Oxygen concentrations and light intensities in the coastal water column near Isla Vista increased over the course of the 3 study days in August 1985 (Table 2).

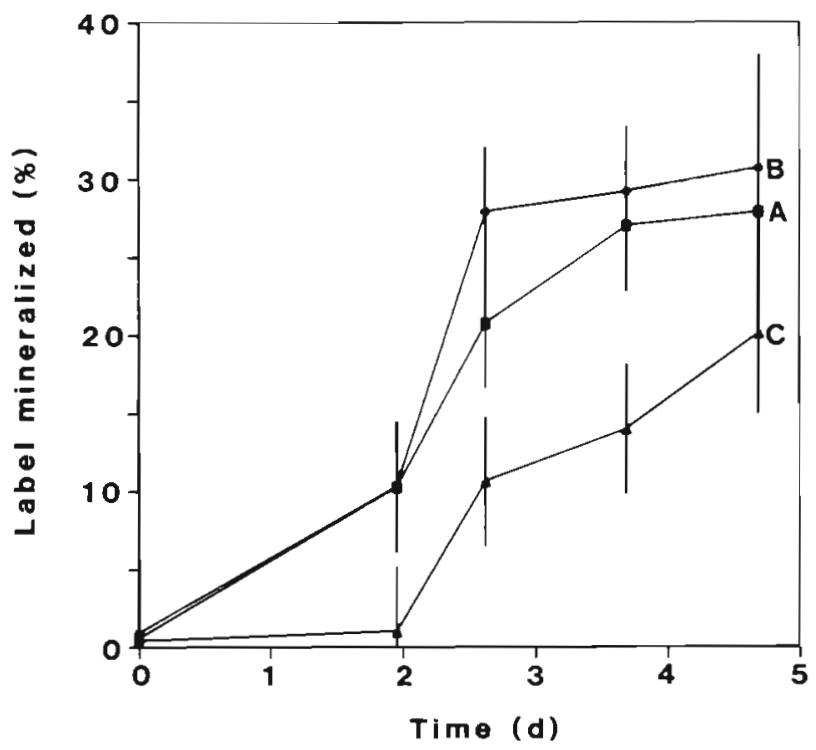

Fig. 5. Mineralization of ${ }^{14} \mathrm{C}$-anthracene to ${ }^{14} \mathrm{CO}_{2}$ by sediment slurries from Stns A, B, and C (0 to $1 \mathrm{~cm}$ depth), Aug 14, 1985.

Vertical bars: $95 \%$ confidence interval of the estimate

The oil slick at the seep might result in reduced benthic light levels, but light intensities were not significantly different among the stations.

None of the processes by which oxygen is consumed or produced were significantly different over stations or dates (Table 3). The average total sediment oxygen demand (SOD) for all dates and stations in August was $62 \mathrm{mmol} \mathrm{m}^{-2} \mathrm{~d}^{-1}$ (standard deviation $=48$ ) and $29 \mathrm{mmol} \mathrm{m}^{-2} \mathrm{~d}^{-1}$ (standard deviation $=21$ ) at Stn B in July. These rates are similar to the values which are predicted by a regression equation given in Hargrave (1969) based on 13 studies of benthic oxygen flux. On the basis of this regression, flux rates of $34 \mathrm{mmol} \mathrm{m}^{-2}$ $\mathrm{d}^{-1}$ at $15.5^{\circ} \mathrm{C}$ (the average August temperature) and $24 \mathrm{mmol} \mathrm{m}{ }^{-2} \mathrm{~d}^{-1}$ at $13.2^{\circ} \mathrm{C}$ (average July temperature) are obtained. The flux rates measured in the present 


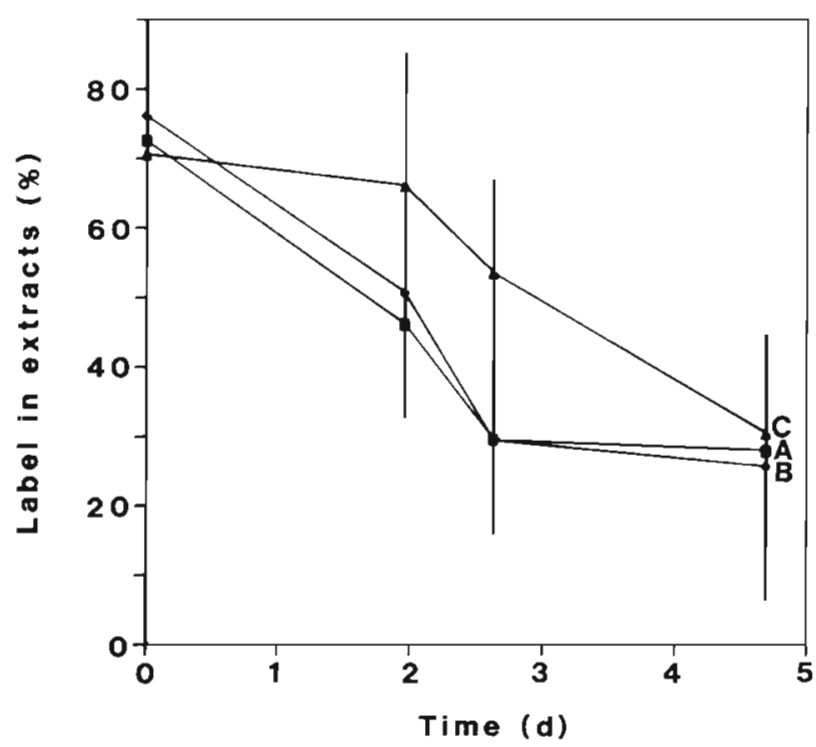

Fig. 6. Anthracene degradation in whole sediment extracts, Aug 14, 1985. Acetone/Sohxlet extracts were performed on sediment slurries from Stns $\mathrm{A}, \mathrm{B}$, and $\mathrm{C}$ at $\mathrm{O}$ to $1 \mathrm{~cm}$ depth. Extracts contained both unaltered ${ }^{14} \mathrm{C}$-anthracene and ${ }^{14} \mathrm{C}$ labeled intermediate metabolites. Extraction efficiencies were 70 to $75 \%$ for anthracene as indicated at time zero.

Vertical bars: $95 \%$ confidence interval of the estimate

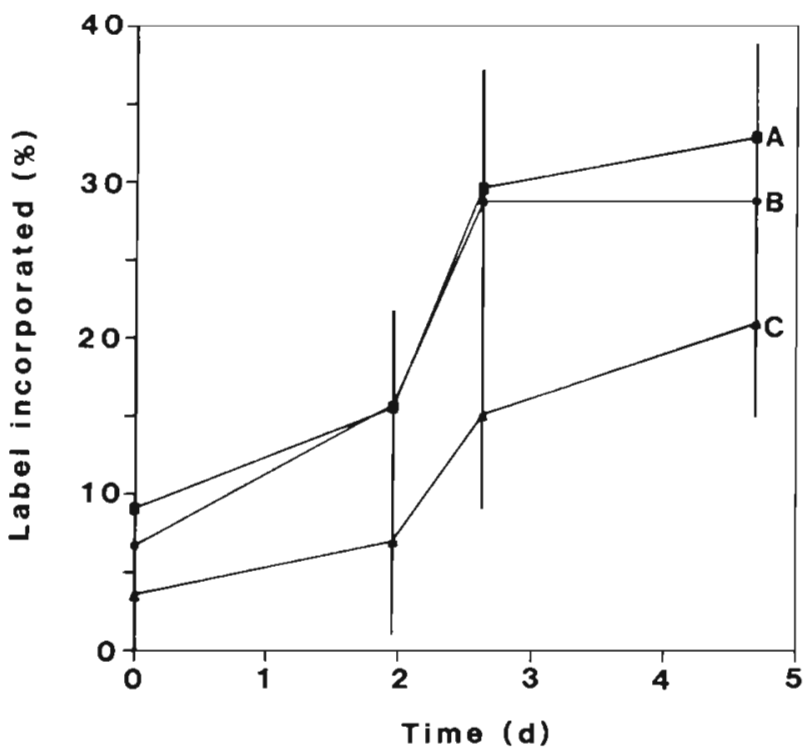

Fig. 7. Anthracene incorporation into cellular biomass from extracted sediments, Aug 14, 1985. Values represent ${ }^{14} \mathrm{C}$ label contained in sediments from Stns $A, B$, and $C$ after incubation of sediment slurries with ${ }^{14} \mathrm{C}$-anthracene and acetone/Sohxlet extraction. Vertical bars: $95 \%$ confidence interval of the estimate

study are also similar to those reported for July and August (31 $\left.\pm 12 \mathrm{mmol} \mathrm{m}^{-2} \mathrm{~d}^{-1}\right)$ at similar depths and sediments near San Diego by Hartwig (1978). It appears that the oxygen flux values measured at the petroleum seep are typical of coastal sandy sediments.
Mineralization rates of model hydrocarbons were greater at Stn B than Stns A and C, which were the same (Table 5). Pool sizes for these compounds were not measured, so that rates (in units of $\mathrm{d}^{-1}$ ) are actually the inverse of the tracer turnover times. The watersoluble fraction of Isla Vista seep oil contains $69 \mathrm{ppb}$ naphthalene (Stuermer et al. 1981), and large amounts of fresh oil are present in sediments in areas of active seepage (similar to Stn A); other areas (e.g. Stns B and C) contain mostly weathered oil and tar (Stuermer et al. 1982). In 1977 total extractable material in sediments was $10.2 \mathrm{mg} \mathrm{g}^{-1}$ at seep Stn B and $2.12 \mathrm{mg} \mathrm{g}^{-1}$ at $\operatorname{Stn} C_{\text {, }}$ and there was more material in the hexane $(19 \times)$ and toluene $(24 \times)$ fractions in $B$ than $C$ sediments (Stuermer et al. 1982). We sampled Stns A, B, and $C$ on 4 dates in 1985, and found $2.1,4.8$ and $1.1 \mathrm{mg}$ extractable material $\mathrm{g}^{-1}$ sediment at the 3 stations (Montagna et al. unpubl.). Because the pool sizes at the seep stations are much greater than those at the comparison site, absolute degradation rates (pool size/ turnover time) are probably 1 to 2 orders of magnitude greater at the seep stations than at the non-seep site.

The seep stations ( $A$ and $B$ ) appear to be a more reducing environment than the comparison station (C). Sulfate reduction (Table 4) and hydrocarbon degradation (Fig. 2 to 5, Table 5) are higher at the seep sites than at the non-seep site. The RPD layer is shallower at the seep relative to non-seep sites (Montagna et al. unpubl.). However, chemical oxygen demand averaged $25 \%$ of total oxygen demand at $\operatorname{Stn} \mathrm{A}, 11 \%$ at Stn $\mathrm{B}$, and $22 \%$ at Stn $\mathrm{C}$, indicating that biologically mediated oxygen flux is the predominant process of oxygen consumption and that the seep stations do not appear to be different from the non-seep station. Only Stn B is in the 10 to $14 \%$ range reported by Boynton et al. (1981) for COD in sandy sediments of Chesapeake Bay. However, Stn B also has the highest rates of sulfate reduction. This raises the question as to how the increased amounts of sulfide produced at Stn B as a result of sulfate reduction are oxidized. One possible explanation is that rates of chemolithotrophic processes are greatest at Stn B. Beggiatoa spp. mats are abundant at the seep (Spies et al. 1980, Montagna \& Spies 1985) and do not occur at the comparison site (Montagna et al. unpubl.).

\section{Oil seep metabolism}

Although there were not significant differences among stations for all of the processes that were measured during this study, there was a trend in the mean rates of oxygen flux, sulfate reduction, and hydrocarbon mineralization which is correlated with the amount of total hydrocarbons extracted from sediments 
Table 6. Grand averages of metabolic rates and total hydrocarbon concentrations in the sediments at 3 sites in and near the Isla Vista petroleum seep in the Santa Barbara Channel

\begin{tabular}{|c|c|c|c|}
\hline \multirow[t]{2}{*}{ Process } & \multicolumn{3}{|c|}{ Station } \\
\hline & A & B & $\mathrm{C}$ \\
\hline $\mathrm{O}_{2}$ flux $\left(\mathrm{mmol} \mathrm{m} \mathrm{m}^{-2} \mathrm{~d}^{-1}\right)$ & -25 & -41 & -12 \\
\hline Sulfate reduction ${ }^{1}\left(\mathrm{mmol} \mathrm{m} \mathrm{m}^{-2} \mathrm{~d}^{-1}\right)$ & 0.91 & 4.1 & 0.66 \\
\hline Hydrocarbon mineralization ${ }^{2}\left(\% \mathrm{~d}^{-1}\right)$ & 6.7 & 10 & 5.1 \\
\hline Total hydrocarbons ${ }^{3}$ ( $\mathrm{g} \mathrm{g}^{-1}$ sediment) & 2.1 & 4.8 & 1.1 \\
\hline \multicolumn{4}{|l|}{${ }^{1}$ To a depth of $5 \mathrm{~cm}$} \\
\hline${ }^{2}$ Average of all tests & & & \\
\hline${ }^{3}$ Data from Montagna et al. unpubl. & & & \\
\hline
\end{tabular}

at the 3 stations (Table 6). In all cases Stn B had the highest rates of oxygen flux, sulfate reduction and hydrocarbon mineralization and the greatest amounts of extractable material, followed by Stn A and then by $C$ which was always ranked third. Since there are 6 possible outcomes in ranking 3 stations, the probability that Stns A, B, and C would be ranked 2, 1, 3 respectively in all 4 cases is $(1 / 6)^{4}$ or 0.00077 . It is highly unlikely that this outcome is due to chance alone. This is strong evidence that higher rates of metabolism are associated with increasing concentrations of total hydrocarbons.

Previously, it was noted that Stn B within the petroleum seep had greater abundances of macroinfauna than the comparison area (Stn C) and there was a gradient of ATP concentrations where $A \geqslant B \geqslant C$ (Spies \& Davis 1979, Davis \& Spies 1980, Spies et al. 1980). Stable isotope ratios of tissues indicated that petroleum-derived carbon was being incorporated into seep invertebrates, and it was further hypothesized that this process was bacterially mediated (Spies \& DesMarais 1983). We have recently found that Stn A has greater bacterial and meiofaunal abundances than either B or C (Montagna et al. unpubl.).

The greater rates of benthic metabolism (found in this study) and infaunal abundances (found in other studies) at the petroleum seep compared to a non-seep site are probabbly the result of complex interactions within the sediments. Heterotrophic bacterial hydrocarbon degradation is predominantly an aerobic process (Atlas 1981) and proceeds rapidly in the surface sediments at the seep. Metabolites of hydrocarbon degradation have been found to include substrates such as acetate, propionate, and butyrate (Ross 1983) which can be utilized by anaerobic sulfate-reducing bacteria (Widdell \& Pfennig 1981, 1982). In typical coastal sandy sediments (e.g. Stn C) where the anoxic zone may be very deep (5 to $10 \mathrm{~cm}$ ), the coupling between aerobically degraded petroleum and anaerobic sulfate reduction might be physically limited either by the distance over which diffusion occurs or by porewater advection. However, at the seep the aerobic-anaerobic interface is very shallow $(0$ to $2 \mathrm{~cm}$ deep) so that such physical limitations do not seem as important. The coupling between petroleum degradation, aerobic respiration, and anaerobic respiration may in part explain the higher microbial productivity observed at the seep (Montagna et al. unpubl.). Thus, petroleum-derived microbial carbon represents an important supplement to the normal trophic processes that contribute to benthic invertebrate productivity and may explain the observed patterns of increased invertebrate abundance found at the oil seep.

Acknowledgements. This work was supported by the U.S. Department of Interior, Minerals Management Service, Pacific Outer Continental Shelf Office, under contract 14-120001-30159 to Kinnetic Laboratories, Inc., and was performed under the auspices of the U.S. Department of Energy by the Lawrence Livermore National Laboratory under contract W7405-Eng-48. We thank S. Anderson, F. Dewitt, J. McCullagh of the University of California, Santa Barbara, and G. Robinson of Santa Barbara City College for help in diving for samples during this project. We thank A. Ebling, F. Harrison, O. Holm-Hansen, N. Lyke, V. Noshkin, and 3 anonymous reviewers for providing constructive comments on earlier versions of the manuscript.

\section{LITERATURE CITED}

Amer. Publ. Health Assoc. (1971). Standard methods for the examination of water and wastewater, 13th edn. Amer. Publ. Health Assoc., New York

Atlas, R. M. (1981). Microbial degradation of petroleum hydrocarbons: an environmental perspective. Microb. Rev. 45: $180-209$

Bauer, J. E., Capone, D. G. (1985). Degradation and mineralization of the polycyclic aromatic hydrocarbons anthracene and naphthalene in intertidal sediments. Appl. environ. Microbiol. 50: 81-90

Boynton, W. R., Kemp, W. M., Osborne, C. G., Kaumeyer, K. P., Jenkins, M. C. (1981). Influence of water circulation rate on in situ measurements of benthic community respiration. Mar. Biol. 65: 185-190

Broenkow, W. W., Cline, J. D. (1969). Colorimetric determination of dissolved oxygen at low concentrations. Limnol. Oceanogr. 14: 450-454 
Cline, J. D. (1969). Spectrophotometric determination of hydrogen sulfide in natural waters. Limnol. Oceanogr. 14: $454-458$

Dale, T. (1978). Total, chemical and biological oxygen consumption of the sediments in Lindaspollene, Western Norway. Mar. Biol. 49: 333-341

Davis, P. H., Spies, R. B. (1980). Infaunal benthos of a natural petroleum seep: study of community structure. Mar. Biol. 59: $31-41$

Hargrave, B. T. (1969). Similarity of oxygen uptake by benthic communities. Limnol. Oceanogr. 14: 801-805

Hartwig. E. O. (1978). Factors affecting respiration and photosynthesis by the benthic community of a subtidal siliceous sediment. Mar Biol. 46: 283-293

Herbes, S. E., Schwall, L. R. (1978). Microbial transformation of polycyclic aromatic hydrocarbons in pristine and petroleum-contaminated sediments. Appl. environ. Microbiol. 35: 306-316

Howarth, R. W. (1984). The ecological significance of sulfur in the energy dynamics of salt marsh and coastal marine sediments. Biogeochemistry 1:5-27

Howarth, R. W., Teal, J. M. (1980). Energy flow in a saltmarsh ecosystem: the role of reduced inorganic sulfur compounds. Am. Nat. 116: 862-872

Howes, B. L., Dacey, J. W. H., King, G. M. (1984). Carbon flow through oxygen and sulfate reduction pathways in salt marsh sediments. Limnol. Oceanogr. 29: 1037-1051

Jørgensen, B. B. (1978). A comparison of methods for the quantification of bacterial sulfate reduction in coastal marine sediments. I. Measurements with radiotracer techniques. Geomicrobiol. J. 1: 11-27

Kempthorne, O., Allmaras, R. R. (1965). Errors in observation. In: Black, C. A. (ed.) Methods in soil analysis. Part 1. Physical and mineralogical properties, including statistics of measurement and sampling. Am. Soc. Agronomy, Madison, p. 1-23

Kirk, R. E. (1982). Experimental design. 2nd edn. Brooks/Cole Publ. Co., Monterey, California

Montagna, P. A., Spies, R. B. (1985). Meiofauna and chlorophyl associated with Beggiatoa mats of a natural submarine petroleum seep. Mar. environ. Res. 16: 231-242

Pamatmat, M. M. (1982). Heat production by sediment: ecological significance. Science 215: 395-396

Pamatmat, M. M., Bhagwat, A. (1973). Anaerobic metabolism in Lake Washington sediments. Limnol. Oceanogr. 18: 611-627

Patching, J. W., Raine, R. C. T. (1983). Benthic metabolism and the supply of organic material to the sea-bed. In: MacDonald, A. G., Priede, I. G. (ed.) Experimental biology at sea. Academic Press, London, p. 311-345

Ross, D. (1983). Ecological studies on sulphate-reducing bacteria in offshore oil storage systems. Ph.D. thesis, HeriotWatt University, Edinburgh

SAS Institute, Inc. (1985). SAS user's guide: statistics, version 5 edition. SAS Institute, Inc., Cary, North Carolina

Spies, R. B., Davis, P. H. (1979). The infaunal benthos of a natural oil seep in the Santa Barbara channel. Mar. Biol. 50: 227-237

Spies, R. B., Davis, P. H., Stuermer, D. H. (1980). Ecology of a submarine petroleum seep off the California coast. In: Geyer, R. A. (ed.) Marine environmental pollution, 1. Hydrocarbons. Elsevier, Amsterdam, p. 229-263

Spies. R. B., DesMarais, D. J. (1983). Natural isotope study of trophic enrichment of marine benthic communities by petroleum seepage. Mar. Biol. 73: 67-71

Stein, J. L. (1984). Subtidal gastropods consume sulfur-oxidizing bacteria: evidence from coastal hydrothermal vents. Science 223: 696-698

Strickland, J. D. H., Parsons, T. R. (1972). A practical handbook of seawater analysis, 2nd edn. Bull. Fish. Res. Bd Can. 167

Stuermer, D. H., Spies, R. B., Davis, P. H. (1981). Toxicity of Santa Barbara seep oil to starfish embryos: Part 1 - Hydrocarbon composition of test solutions and field samples. Mar. environ. Res. 5: 275-286

Stuermer, D. H., Spies, R. B., Davis, P. H., Ng, D. J., Morris, C. J., Neal, S. (1982). The hydrocarbons in the Isla Vista marine seep environment. Mar. Chem. 11: 413-426

Widdell, F., Pfennig. N. (1981). Studies on dissimilatory sulfate-reducing bacteria enriched with acetate from saline environments. Description of Desulfobacter postgate: gen. nov., sp. nov. Arch. Mikrobiol. 129: 395-400

Widdell, F., Pfennig, N. (1982). Studies on dissimilatory sulfate-reducing bacteria that decompose fatty acids. II. Incomplete oxidation of propionate by Desulfobulbus propionicus gen. nov., sp. nov. Arch. Mikrobiol. 131: 360-365 